\title{
Analysis of the educational design activity in the field of cold pressing technology by means of the axiomatic design
}

\author{
Gheorghe Nagîț ${ }^{1}$, Oana Dodun ${ }^{2, *}$, Margareta Coteață, Petru Dușa, Marius Ionuț Rîpanu, Adelina Hrițuc, and Laurențiu \\ Slătineanu \\ 1 "Gheorghe Asachi” Technical University of Iași, Department of Machine Manufacturing Technology, Blvd. D. Mangeron, 59 A, \\ 700050 Iași, România
}

\begin{abstract}
Within the university study program that trains of the future engineers in the field of manufacturing engineering, in the Romanian technical universities, there are matters that aim at familiarizing students with the way of solving certain problems of constructive and/or technological design. Such a matter, called cold pressing technology, has been included in the last years of the license studies. In the context of the project activity at this matter, as a theme to be solved, the student usually receives the responsibility of designing a mold for the cold-pressing of pieces of various shapes, for large series production, starting from sheet type workpiece. The passing of successive design stages gradually leads the student to elaborate a project that includes an assembly drawing and some mechanical drawings as final documents related to the received project theme. It was considered that by using some principles of axiomatic design, it is possible to investigate and define more clearly the objectives of the project activity in the field of cold pressing technology. The analysis allowed a clearer definition of functional requirements and the identification of solutions to improve the quality of future engineer training activities concerning to project activity in the field of cold pressing technology.
\end{abstract}

\section{Introduction}

Generally, engineering defines the profession of the engineer. It is considered that the engineer is a specialist that has a technical and theoretical training obtained in a high education institute and which achieves an activity of designing, organizing and leading the technological processes in an enterprise.

As above mentioned, to be entitled to use the title of engineer, a specialist must graduate a university which trains engineers. Due to the large variety of technical problems, an extended set of engineering specialties exist and the universities could ensure the adequate training of the future engineers in very distinct fields.

One of such fields is manufacturing engineering. Essentially, the engineering specialist in the field of manufacturing engineering has proper responsibilities concerning the design and applying the processes of manufacturing of all the technical products requested by human society.

It may be mentioned that in many countries advanced from the economical point of view, it was preferred to train a specialist in a general field of mechanical engineering or industrial engineering and only by master courses or subsequent training in the enterprise, the knowledge and the competencies specific to an engineer specialized in the field of manufacturing engineering could be obtained.
In Romania and the other countries, just from the beginning of the university studies, it was preferred to train the engineers specialized in the field of manufacturing engineering. Taking into consideration the real conditions from such countries, it was considered that the training of the engineers in the field of manufacturing engineering was a good thing and studies programs in this field are yet included in the didactic activities of the technical universities or of other universities that train the future engineers.

In Romania, it is considered that the engineers specialized in the field of manufacturing engineering have a high adaptability level, due to their larger training field. They could work both as designers of mechanical equipment and technology of mechanical equipment manufacturing.

Considering the manufacturing engineers education as a system, it can be appreciated that their training should ensure professional knowledge and competencies valid for about 10 years and flexibility/adaptability for about $40-50$ years (fig. 1).

If we limit the analysis to the field of manufacturing engineering, as above-mentioned, it can be noticed that the graduates could work both as designers of manufacturing technologies, and as coordinators of the applying the manufacturing technologies in the manufacturing/mechanical workshops.

\footnotetext{
* Corresponding author: oanad@tcm.tuiasi.ro
} 


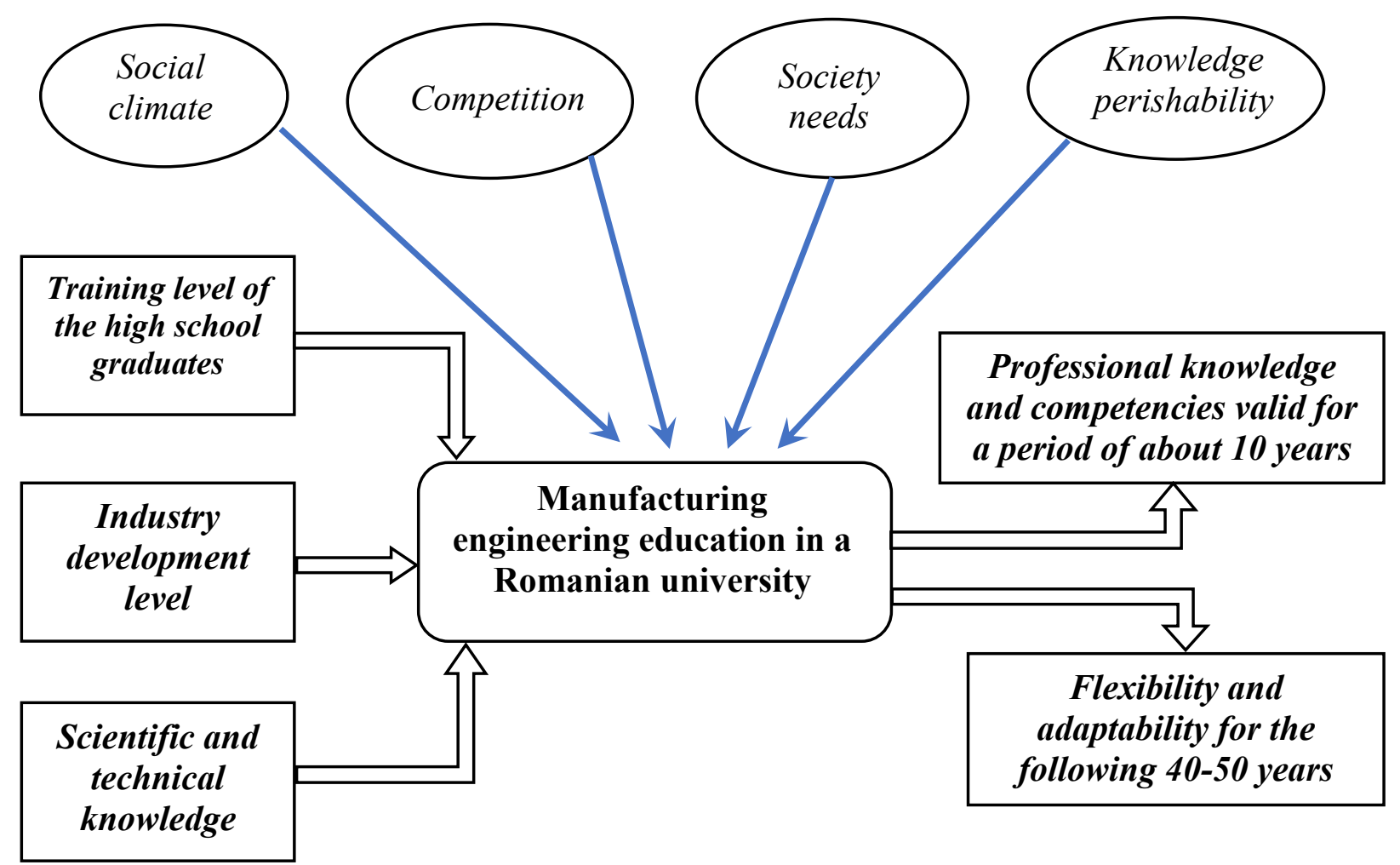

Fig. 1. Manufacturing engineering education as a system (adapted from [1])

Within the training of the engineers specialized in the field of manufacturing technologies, there are two categories of university matters: base matters and specialty matters. As specialized matters, we consider the machine manufacturing technology, machine tools, tools design, cold pressing technology, thermal treatments, computer-assisted technological design, etc.

The cold pressing technology aims to initiate and familiarize the future engineer in the field of designing and applying in practice the cold pressing processes. As the main objective included in the matter study curriculum, the transmitting knowledge concerning the scientific fundamentals of the cold plastic deformation and the selection and use of the equipment and tools necessary in applying the plastic deformation processes to the students are mentioned.

Over the years, some aspects of the cold plastic processes were approached inclusively by means of the axiomatic design principles.

Thus, professor Nam Suh took into consideration the use of the axiomatic design when the problem of developing an intelligent brakeforming machine was stated. He appreciated that using the axiomatic design the machines could be made more intelligent [2]. A case study concerning the achievement of the correct bend angle was selected to prove that an intelligent machine does not need a large data bank on materials and operating conditions or closed-loop feedback control.

Christopher Brown discussed in some works the problem of using the axiomatic design in university teaching activities. Thus, he considered that the axiomatic design as a useful tool in understanding the axiomatic design as a science [3]. Two essential functional requirements could be valid in the design of any manufacturing process, namely those who request to maximize value-added and to minimize costs.

Brown noticed also that when there are more than a few functional requirements, a certain difficulty is felt by the engineers in the design problem management [4]. A possible solution to diminish the difficulty effects could be based on the use of certain design software and an example of such software could be Acclaro.

Ample research concerning the use of the axiomatic design in considering engineering education as a manufacturing system was developed by Walter Towner in a dissertation elaborated under professor Christopher Brown's coordination. As the main conclusion, Towner appreciated that the design of engineering education as a manufacturing system is characterized by adjustability, controllability, cost efficiency and ability to be put into operation [5].

The problem of using the axiomatic design in the educational processes was approached also by other researchers [ 6-18].

The objective of this paper was to develop an evaluation of the design activity developed in connection with the university matter called "cold pressing technology" using the principles specific to the axiomatic design, taking into consideration especially the functional requirements and design parameters. 


\section{Initial considerations}

In the so-called curricula for training future engineers in the field of manufacturing engineering, there are some university matters that intend to develop their knowledge and competencies of constructive or constructivetechnological design.

For example, it is considered that the applicative design activities associated with the mater "Machine elements" could familiarize the student with the problems that correspond to the design of mechanical equipment. This could be the first answer to the problem of initiating the students in the field of constructive design.

On the other hand, in the curricula for the study program in the field of manufacturing engineering, there are some university matters intended to associate the problems of constructive design with the technological design. Thus, the student could assimilate and use knowledge and competencies concerning the design of machine tools, cutting tools, technological devices and dies/molds for cold pressing processes.

Usually, the coordinators of the university matters propose the curricula of the matters and there are some stages in which these structures are approved or requests of modifying or completing the structures could be formulated. It can be noticed that even the interest of developing the students' abilities in the field of constructive design or technological design are common, there were no circumstances in which changes of the points of view about such an aspect could be analyzed.

Taking into consideration this situation, an attempt to make more clear the requirements and of the ways to answer these requirements by means of the axiomatic design was proposed.

As the first step, it is accepted that the functional requirement of zero-order could be: FR0: initiate and familiarize the student with the problems specific to the constructive or constructive-technological design.

In a simplified example, on the base of the functional requirement of zero-order, the functional requirements of the first order could be formulated:

- FR1: Ensure the understanding of the functional role of the part for which technological equipment necessary in its manufacturing process could be designed;

- FR2: Verify the correctness of the mechanical design; FR3: Verify the producibility of the part presented in the part design;

- FR4: Design one or more versions of the manufacturing routings able to allow the obtaining of the part;

- FR5: Select the most convenient version of manufacturing routing;

- FR6: Identify the tools, devices and machine tools that could be used in materializing the selected manufacturing routing;

- FR7: Design established technological equipment (tools, devices, machine tools) that could be used in the manufacturing routing;

- FR8: Develop the student technical creativity;

- FR9: Familiarize the student with the problem of analysis and elaborating designs for parts or assemblies;

- FR10: Familiarize the student with the way of establishing the tolerances of parts and assemblies;

- FR11: Develop the students' ability to imagine spatial structures;

-FR12: Develop the students' ability for teamwork.

Once established the above mentioned functional requirements valid in the case of the elaboration a constructive-technological design, the following design parameters could be taken into consideration:

- $D P 1$ : Analysis of the role of the part;

- DP2: Written comments concerning the evaluation of the technical design correctness;

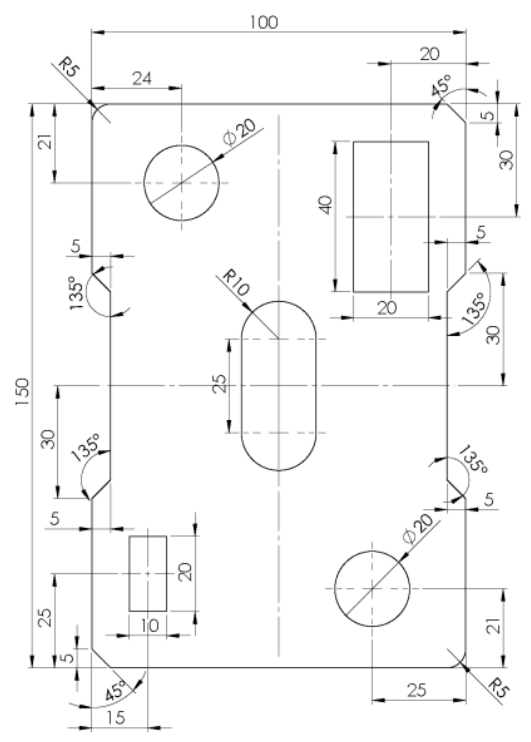

Fig. 1. Two examples of parts for which the manufacturing technology and tools must be designed. 
Table 1. Matrix that includes the functional requirements and design parameters for the activity of designing technological equipment.

\begin{tabular}{|c|c|c|c|c|c|c|c|c|c|c|c|c|c|c|}
\hline Line & \multirow{5}{*}{\multicolumn{2}{|c|}{ Design parameters }} & \multicolumn{11}{|c|}{ Design parameters } & \\
\hline 2 & & & \multicolumn{11}{|c|}{ Design parameters of zero order } & \\
\hline 3 & & & \multicolumn{11}{|c|}{ DP1: Supporting documents and die design } & \\
\hline 4 & & & \multicolumn{11}{|c|}{ Design parameters of the second order } & \\
\hline 5 & & & $\begin{array}{c}D P 1: \\
\text { analy- } \\
\text { sis of } \\
\text { the } \\
\text { part } \\
\text { role }\end{array}$ & \begin{tabular}{|c|}
$D P 2:$ \\
Writ- \\
ten \\
com- \\
ment \\
con- \\
cer- \\
ning \\
design \\
cor- \\
rect- \\
ness
\end{tabular} & $\begin{array}{c}D P 3: \\
\text { Writ- } \\
\text { ten } \\
\text { com- } \\
\text { ment } \\
\text { con- } \\
\text { cer- } \\
\text { ning } \\
\text { part } \\
\text { produ- } \\
\text { cibi- } \\
\text { lity }\end{array}$ & $\begin{array}{c}D 4: \\
\text { Ver- } \\
\text { sions } \\
\text { of } \\
\text { manu- } \\
\text { factu- } \\
\text { ring } \\
\text { rou- } \\
\text { tings }\end{array}$ & $\begin{array}{c}\text { DP5: } \\
\text { Opti- } \\
\text { mal } \\
\text { ver- } \\
\text { sion } \\
\text { selec- } \\
\text { ted }\end{array}$ & \begin{tabular}{|c|}
$D P 6:$ \\
Equip- \\
ment \\
esta- \\
bli- \\
shed
\end{tabular} & $\begin{array}{c}D P 7: \\
\text { Equip- } \\
\text { ment } \\
\text { desig- } \\
\text { ned }\end{array}$ & $\begin{array}{c}\text { DP8: } \\
\text { Dis- } \\
\text { tinct } \\
\text { ver- } \\
\text { sions } \\
\text { of } \\
\text { manu- } \\
\text { factu- } \\
\text { ring } \\
\text { rou- } \\
\text { tings }\end{array}$ & \begin{tabular}{|c}
$D P 9:$ \\
Use of \\
assi- \\
milla- \\
ted \\
know- \\
ledge \\
or \\
profes- \\
sional \\
hand- \\
books
\end{tabular} & \begin{tabular}{|c|}
$D P 10:$ \\
Use of \\
assi- \\
milla- \\
ted \\
know- \\
ledge \\
or \\
profes- \\
sional \\
hand- \\
books
\end{tabular} & $\begin{array}{c}D P 11: \\
\text { Men- } \\
\text { tal } \\
\text { exer- } \\
\text { cise } \\
\\
\end{array}$ & $\begin{array}{c}D P 12: \\
\text { Inclu- } \\
\text { ded } \\
\text { colla- } \\
\text { bora- } \\
\text { tion } \\
\text { tasks }\end{array}$ \\
\hline $\begin{array}{c}6 \\
\text { Co- } \\
\text { lumn } \\
\text { no. } 1 \\
\end{array}$ & 2 & 3 & 4 & 5 & 6 & 7 & 8 & 9 & 10 & 11 & 12 & 13 & 14 & 15 \\
\hline 7 & \begin{tabular}{|c|} 
Functional \\
requirement of \\
the zero order \\
\end{tabular} & $\begin{array}{c}\text { Functional } \\
\text { requirements of the } \\
\text { first level }\end{array}$ & \multicolumn{12}{|c|}{ Design parameter $D P$ that corresponds to each functional requirement } \\
\hline 8 & & $\begin{array}{l}\text { FR1: Understand the } \\
\text { functional part role }\end{array}$ & $\mathrm{X}$ & & & & & & & & & & & \\
\hline 9 & & $\begin{array}{l}F R 2: \text { Verify the } \\
\text { correctness of the } \\
\text { mechanical design }\end{array}$ & & $\mathrm{X}$ & & & & & & & & & & \\
\hline 10 & & $\begin{array}{c}\text { FR3: Verify the } \\
\text { manufacturability of } \\
\text { the part }\end{array}$ & & & $\mathrm{X}$ & & & & & & & & & \\
\hline 11 & & $\begin{array}{c}F R 4 \text { : Design more } \\
\text { versions of the } \\
\text { manufacturing } \\
\text { routing }\end{array}$ & & & & $\mathrm{X}$ & & & & & & & & \\
\hline 12 & $\begin{array}{c}F R 0: \\
\text { familiarize the }\end{array}$ & $\begin{array}{l}\text { FR5: Select the } \\
\text { optimal } \\
\text { manufacturing } \\
\text { routing }\end{array}$ & & & & & $X$ & & & & & & & \\
\hline 13 & $\begin{array}{c}\text { student with } \\
\text { the problems } \\
\text { of constructive }\end{array}$ & $\begin{array}{c}\text { FR6: Identify tools, } \\
\text { devices and machine } \\
\text { tools }\end{array}$ & & & & & & $X$ & & & & & & \\
\hline 14 & $\begin{array}{c}- \\
\text { technological } \\
\text { design }\end{array}$ & \begin{tabular}{|c|}
$F R 7:$ Design \\
technological \\
equipment
\end{tabular} & & & & & & & $\mathrm{X}$ & & & & & \\
\hline 15 & & $\begin{array}{l}\text { FR8: Develop the } \\
\text { technical creativity }\end{array}$ & & & & & $X$ & & & $X$ & & & & \\
\hline 16 & & $\begin{array}{c}\text { FR9: Familiarize } \\
\text { with the analysis } \\
\text { and elaboration of } \\
\text { part design }\end{array}$ & & & & & & & & & $\mathrm{X}$ & $\mathrm{X}$ & & \\
\hline 17 & & $\begin{array}{c}F R 10: \text { Familiarize } \\
\text { with the problems of } \\
\text { tolerancing }\end{array}$ & & & & & & & & & $\mathrm{X}$ & & & \\
\hline 18 & & $\begin{array}{l}F R 11: \text { Develop the } \\
\text { ability to imagine } \\
\text { spatial structures }\end{array}$ & & & & & & & & & & & $X$ & \\
\hline 19 & & $\begin{array}{l}\text { FR12: Develop the } \\
\text { students' ability for } \\
\text { team work }\end{array}$ & & & & & & & & & & & & $X$ \\
\hline
\end{tabular}


- DP3: Written comments concerning the evaluation of the part producibility;

- DP4: One or more versions of manufacturing routing elaborated;

-DP5: Optimal version selected;

- DP6: Technological equipment established;

- DP7: Technological equipment designed;

- DP8: Distinct versions of the manufacturing routings considered;

- DP9: Use of already assimilated knowledge or of professional handbooks;

- DP10: Use of already assimilated knowledge or of professional handbooks;

- DP11: Mental exercise to imagine the spatial assemblies and parts;

- DP12: Included collaboration tasks.
It can be noticed that 7 of the above mentioned functional requirements and design parameters designate particular aspects of the constructive - technological design, while the last 5 functional requirements and design parameters have a more general character.

At the same time, it can be seen that a large set of design stages were simply mentioned by means of the functional requirements FR7.

The analysis could continue by considering the functional requirements and design parameters of second-order, but for this attempt to analyze the possible correlations between the functional requirements and design parameters, it has been appreciated that the analysis could be limited to the above-mentioned stages.

A version of the matrix including the functional requirements and design parameters is presented in
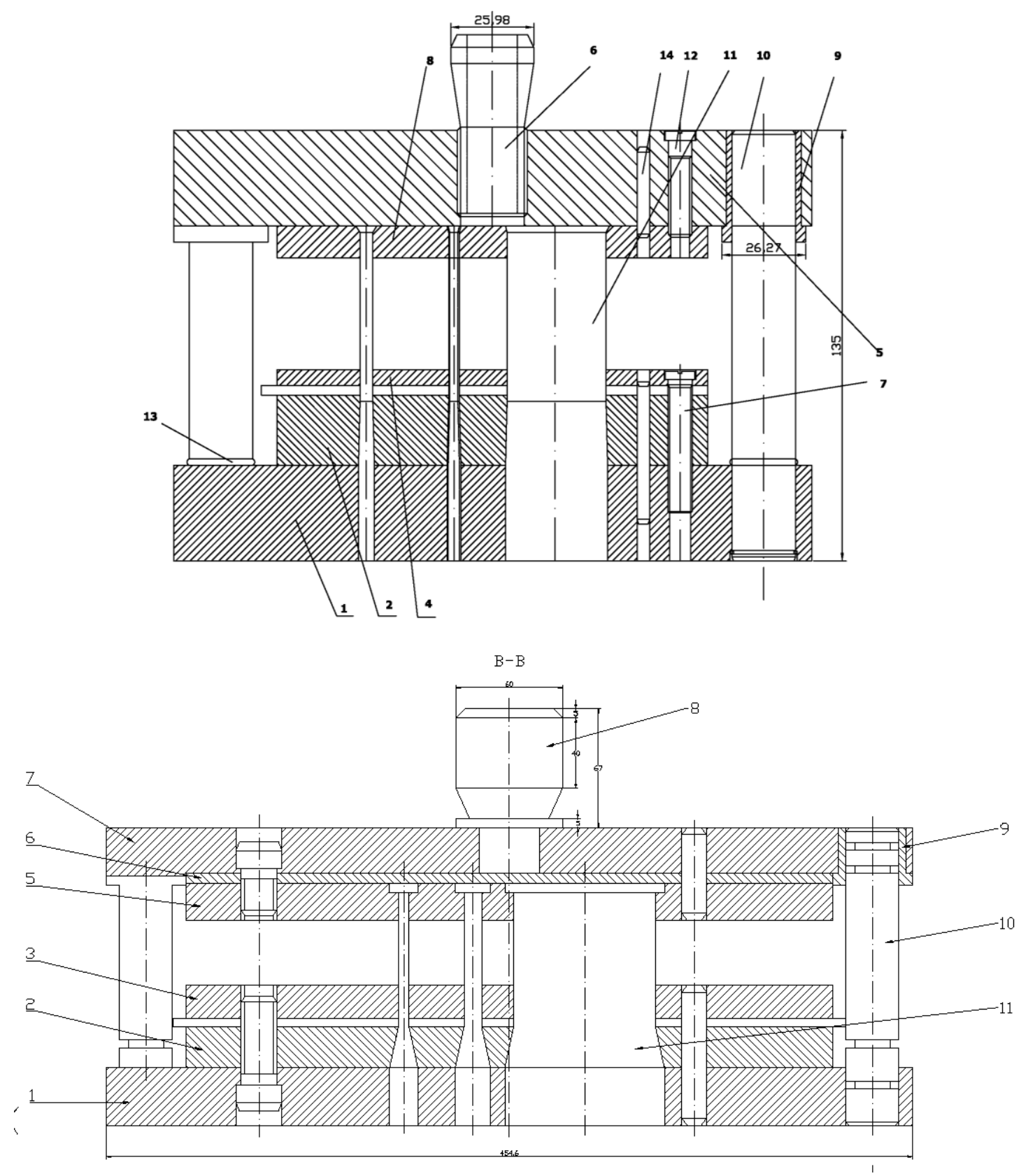

Fig. 3. Examples of dies designed by the students within the design activity at the matter called cold pressing technology. 
table 1; it can be noticed that a decoupled design corresponds to this matrix.

\section{Context of the university matter concerning the cold pressing technology}

The university matter named "cold pressing technology" was included in the semesters 6 and 7 of the training in the field of the study program of the machine manufacturing technology. A semester has a duration of 17 weeks for lectures and applicative activities. In the $6^{\text {th }}$ semester, there are 3 lectures hours per week, 1 hour/week for laboratory activities an 1 hour/week for design activity. In the $7^{\text {th }}$ semester, there are 2 hours/week for courses, 1 hour/week for design activities and 1 hour/week for laboratory activities.

The general structure of the lectures included chapters for the presentation of the theory of cold plastic deformation, the various techniques of processing by cold plastic deformation, assembling processes by plastic deformation, ways of designing and economical evaluation of the cold plastic deformation processes.

The laboratory activities aim to familiarize the students with the cold pressing equipment and their use in developing processes of cold pressing technology.

The design activity aims to develop the student's knowledge and competencies concerning the design of a cold pressing process and tools that could be used in large series production of a certain part (fig. 1).

The objective of the design activity is to design the technological process and the die for obtaining a part in accordance with a certain part design in the case of a series or mass production by successive punching processes.

The main design stages [19-22] are the following: 1. Analysis of the initial information (of the possibility to obtain the part when considering the recommended material, particularly of the information included in the part design, of the part producibility. Establishing the technological dimensions for the blank; 2. Development of technological calculus. Elaboration of three versions for the manufacturing routing. Adoption or calculus of some essential dimensions of the blank. Calculus of the material use coefficient. Evaluation of the quantity of blanks necessary to obtain the requested number of parts. Adoption of the manufacturing routing able to ensure the maximum use of the blank. Elaboration of the first sketch of the die; 3 . Calculus of the cutting forces, energy, and power necessary in the punching process; 4. Establishing the die components dimensions; 5 . Establishing the tolerances of the die active elements; 6 . Selection of the pressing equipment; 7. Establishing the time required per operation. Determining the part cost; 7 . Elaboration of the die assembly design.

During each of the semesters, the student design activity is followed and evaluated by the coordinator of the design activity. At the end of the semester, the student must have elaborated supporting documents, at least a die assembly design and several parts designs by which he could prove the assimilation of certain applicative design knowledge and competencies in the field of cold pressing technology.

In establishing the final mark at university matter of cold pressing technology, the examiner takes into consideration the design activity in a proportion of $15 \%$, the laboratory activity in a proportion of $10 \%$ and the oral answers to the questions from the exam ticket in a proportion of $75 \%$. Two examples of dies and molds elaborated by the students during the design activities are shown in figure 2.

Within this paper, it was also intended to develop an analysis by means of the requirements specific to the axiomatic design, in order to evaluate if the current structure and design activity developed in the university matter named cold pressing technology answers adequately the objective of a good training of the future engineer in the field of parts manufacturing by cold plastic deformation processes.

\section{Applying some axiomatic design principles in the case of design activity at the university mater of cold pressing technology}

To apply some of the principles of the axiomatic design, the client's needs can be defined first. In this case, society in general or the university, in particular, could be considered as a client. The client needs valid in the case of the design activity that corresponds to the cold pressing technology matter could be: ensure the initiation and the familiarizing the students with the knowledge and competencies necessary to design the technological process and the adequate tools for manufacturing a part by cold pressing technology.

Accordingly to these client needs, the functional requirement of zero-order $F R 0$ could be: ensure the stages and their content for developing a design activity aiming at defining the technological process and the adequate tool for manufacturing a part by cold pressing processes. The functional requirements of the first order could be: FR1: Ensure the student's knowledge of the ways in which the initial information is complete and correct; FR2: Ensure the student's knowledge of how some initial dimensions that correspond to the blank could be determined; FR3: Select the most convenient manufacturing routing among three versions of manufacturing routings designed, partially developed and evaluated; FR4: Calculate the forces, energy and power necessary in the cold plastic deformation process; FR5: Establish the dimensions of the main die components; FR6: Establish the dimensions and tolerances for the die active components; $F R 7$ : Select the cold pressing equipment; FR8: Establish the time required per operation; $F R$ 9: Determine the manufactured part cost; FR10: Elaborate the assembly design of the die.

The design parameters that correspond to the functional requirements of first-order could be: $D P 1$ : Students comments included in the project document and concerning the correctness of the part mechanical drawing and the part manufacturability; DP2: Initial 
dimensions that correspond to the blank calculated; $D P 3$ : Optimal manufacturing routing established; DP4: Values calculated for the forces, energy and power necessary in the cold plastic deformation process; DP5: Dimensions established for the die base components; DP6: Dimensions and tolerances established for the die active components; DP7: Cold pressing equipment established; DP8: Time per operation calculated; DP9: Manufactured part cost established; DP10: Assembly design of the die elaborated.

The analysis could continue by considering the functional requirements of the second-order and identifying the design parameters of the second-order and so on.

\section{Remarks derived from the analysis by means of the axiomatic design}

The analysis of the design activity developed in connection with the university matter "could pressing technology" facilitated the clarifying of the objectives susceptible to be met by means of such an activity. New functional requirements or functional requirements that were less taken into consideration during the time allocated to this activity have been identified.

Thus, it is noticed that the actual curriculum takes into account the stimulation of the students technical creativity to a lesser extent and improved solutions for

Table 2. Matrix that includes the functional requirements and design parameters for a die.

\begin{tabular}{|c|c|c|c|c|c|c|c|c|c|c|c|c|}
\hline Line & \multirow{5}{*}{\multicolumn{2}{|c|}{ Design parameters }} & \multicolumn{10}{|c|}{ Design parameters } \\
\hline 2 & & & \multicolumn{10}{|c|}{ Design parameters of zero order } \\
\hline 3 & & & \multicolumn{10}{|c|}{ DP0: Supporting documents and die design } \\
\hline 4 & & & \multicolumn{10}{|c|}{ Design parameters of the second order } \\
\hline 5 & & & $\begin{array}{c}D P 1: \\
\text { Writ- } \\
\text { ten } \\
\text { stu- } \\
\text { dent } \\
\text { com- } \\
\text { ments }\end{array}$ & $\begin{array}{c}D P 2: \\
\text { Initial } \\
\text { dimen- } \\
\text { sions } \\
\text { of the } \\
\text { blank }\end{array}$ & $\begin{array}{l}\text { DP3: } \\
\text { Opti- } \\
\text { mal } \\
\text { manu- } \\
\text { factu- } \\
\text { ring } \\
\text { rou- } \\
\text { ting }\end{array}$ & $\begin{array}{c}\text { DP4: } \\
\text { Calcu- } \\
\text { lated } \\
\text { forces, } \\
\text { energy } \\
\text { and } \\
\text { power }\end{array}$ & \begin{tabular}{|c|}
$D P 5:$ \\
Dimen- \\
sions of \\
the \\
main \\
die \\
compo- \\
nents \\
\end{tabular} & \begin{tabular}{|c}
$D P 6:$ \\
Dimen- \\
sions \\
and to- \\
leran- \\
ces of \\
the die \\
active \\
compo- \\
nents
\end{tabular} & $\begin{array}{c}D P 7: \\
\text { Cold } \\
\text { pres- } \\
\text { sing } \\
\text { equip- } \\
\text { ment }\end{array}$ & $\begin{array}{l}\text { DP8: } \\
\text { Machi- } \\
\text { ning } \\
\text { time }\end{array}$ & $\begin{array}{c}D P 9: \\
\text { Manu- } \\
\text { factu- } \\
\text { red } \\
\text { part } \\
\text { cost }\end{array}$ & $\begin{array}{l}D P 10: \\
\text { Die } \\
\text { assem- } \\
\text { bly } \\
\text { design }\end{array}$ \\
\hline $\begin{array}{c}6 \\
\text { Co- } \\
\text { lumn } \\
\text { no. } 1 \\
\end{array}$ & 2 & 3 & 4 & 5 & 6 & 7 & 8 & 9 & 10 & 11 & 12 & 13 \\
\hline 7 & \begin{tabular}{|c|} 
Functional \\
requirement of the \\
zero order \\
\end{tabular} & $\begin{array}{c}\text { Functional requirements } \\
\text { of the first level }\end{array}$ & \multicolumn{10}{|c|}{ Design parameters DPs that correspond to each functional requirement } \\
\hline 8 & \multirow{10}{*}{$\begin{array}{c}\text { FR0: } \\
\text { Ensure the stages } \\
\text { for designing the } \\
\text { manufacturing } \\
\text { process and the } \\
\text { die necessary to } \\
\text { obtain a part by } \\
\text { cold plastic } \\
\text { deformation }\end{array}$} & $\begin{array}{l}F R 1 \text { : Verify the } \\
\text { correctness and } \\
\text { completeness of the } \\
\text { initial information }\end{array}$ & $\mathrm{X}$ & & & & & & & & & \\
\hline 9 & & $\begin{array}{c}F R 2 \text { : Establish the blank } \\
\text { main dimensions }\end{array}$ & & X & & & & & & & & \\
\hline 10 & & $\begin{array}{c}F R 3 \text { : Select the } \\
\text { manufacturing routing }\end{array}$ & & & $\mathrm{X}$ & & & & & & & \\
\hline 11 & & $\begin{array}{c}\text { FR4: Determine the } \\
\text { forces, energy and } \\
\text { power necessary in the } \\
\text { cold plastic deformation } \\
\text { process }\end{array}$ & & & & $\mathrm{X}$ & & & & & & \\
\hline 12 & & $\begin{array}{c}\text { FR5: Establish the } \\
\text { dimension of the main } \\
\text { die components }\end{array}$ & & & & & $\mathrm{X}$ & & & & & \\
\hline 13 & & $\begin{array}{l}\text { FR6: Establish the } \\
\text { dimensions and } \\
\text { tolerances for the die } \\
\text { active components }\end{array}$ & & & & & & $\mathrm{X}$ & & & & \\
\hline 14 & & $\begin{array}{l}F R 7 \text { : Establish the cold } \\
\text { pressing equipment }\end{array}$ & & & & & & & $X$ & & & \\
\hline 15 & & $\begin{array}{l}\text { FR8: Establish the time } \\
\text { per operation }\end{array}$ & & & & & & & & $X$ & & \\
\hline 16 & & $\begin{array}{l}\text { FR9: Determine the } \\
\text { manufacturing cost }\end{array}$ & & & & & & & & & $X$ & \\
\hline 17 & & $\begin{array}{l}\text { FR10: Elaborate the die } \\
\text { assembly design }\end{array}$ & & & & & & & & & & $X$ \\
\hline
\end{tabular}


this problem must be found in the future.

Another problem for which adequate answer must be found refers to the stimulation of the teamwork; it has been noticed that the current way of developing the design activity in connection with the university matter "cold pressing technology" does not stimulate sufficiently the collaboration among the students to reach common objectives.

It is also noticed that improvements are possible in connection with the assuming by the student of higher responsibility in developing a good quality project.

Another remark was made in connection with the less use of the impressive volume of scientific and technical information that exists on the internet; it has been appreciated that a higher accent could be directed on such a problem.

\section{Conclusions}

In the university training of the future engineer specialist in the field of manufacturing engineering, some university matters are aiming at initiating and familiarizing the students with the problems specific to the constructive or constructive - technological design. Such a university matter is the cold pressing technology. It was considered that an analysis of the design activity associated with the matter entitled "cold pressing technology" could be made by using some of the principles of the axiomatic design. With this aim in view, an initial analysis concerning some general functional requirements that correspond to the matters involving the constructive - technological design was developed. In the second stage, the functional requirements specific to the matter "cold pressing technology" were considered. The analysis highlighted certain aspects that are less approached by the current design activity or real ways to improve student design activity. Thus, it was noted the necessity to improve the stimulation of the student's technical creativity, to include ways of improving the teamwork, to use the information offered by the internet at a larger extent.

\section{References}

1. L. Slătineanu, G. Nagîț, O. Dodun, M. Coteață, A. Iosub, Ways for the education of the future engineers in the field of manufacturing engineering, Communication in DET2008, Nantes, 2008

2. N.P. Suh, The principles of design (Oxford University Press, 1990)

3. C.A. Brown, J. Manuf. Syst., 24, 3 (2005)

4. C.A. Brown, Elements of Axiomatic Design: a simple and practical approach to engineering design. Draft (Cazenovia, New York, 2006)

5. W.T. Towner, The design of engineering education as a manufacturing system. Dissertation (Worcester Polytechnic Institute, 2013)

6. N.P. Suh. Teaching students to be more creative through formal pedagogy. In the brochure "Doctor
Honoris causa. Nam Pyo Suh" ("Gheorghe Asachi” Technical University of Iași, Romania, 2017

7. M.K. Thompson, Proceedings of ICAD 2009, ICAD-2009-20

8. A. Liu, S. Lu, Proceedings of ICAD2013, ICAD2013-15

9. A. Liu, MATEC Web Conf., 223, 2018, 01017

10. E. Odom, S. Beyerlein, C.A. Brown, D. Drew, L. Gallup, S. Zimmerman, and J. Olberding, Proceedings of the 2005 American Society for Engineering Education Annual conference \& Exposition, available: https://www.researchgate. net/publication/268394725_Role_of_Axiomatic_De sign in Teaching Capstone Courses, accessed: 29.04.2019

11. M. Nordlund, S.-G. Kim, D. Tate, T. Lee, and H. Oh, Procedia CIRP 50, 216 - 221 (2016)

12. G. Arcidiacono, K. Yang, J. Trewn, L. Bucciarelli, Procedia CIRP 53, 166 - 172 (2016)

13. G.-J. Park, Proceedings of ICAD2011, ICAD-201129 (2011)

14. G.-J. Park, J. Mech. Sci. Technol. 28 (3), 989 998 (2014)

15. J.T. Foley, E. Puik, and D.S. Cochran, MATEC Web of Conferences 127, 01009 (2017)

16. J. T. Foley, S. Harðardóttir, Procedia CIRP 50, 240 -245 (2016)

17. K. Iino, M. Nakao, Procedia CIRP 53, 173 - 178 (2016)

18. L. Slătineanu, O. Dodun, N. Seghedin, M. Coteaţă, I. Beşliu, L. Gherman, Proceedings of ICAD2014, ICAD-2014-07 (2014)

19. G. Nagîţ, V. Braha, B. Rusu, Fundamentals of plastic deformation processing (in Romanian) (Publishing House Tehnica - Info, Chişinău, Republic of Moldova 2002)

20. D.H. Nelson, G. Schneider, Jr., Applied manufacturing process planning with emphasis on metal forming and machining (Prentice Hall, Upper Saddle River, 2001)

21. B. Balakshin, Fundamentals of Manufacturing Engineering (Mir Publishers, Moscow, 1971)

22. V. Danilevsky, Manufacturing Engineering (Mir Publishers, Moskow, 1973) 